\title{
THE POSITIONING MATTERS OF THE DOLL'S HOUSE IN POSTCOLONIALISM
}

\author{
Dwi Mega Fitriana \\ Department of English Teaching \\ Faculty of Letters and Arts Education IKIP PGRI Madiun \\ dwi_megha@rocketmail.com
}

\begin{abstract}
The purpose of this research is to analyze the self-positioning and social class phenomenon of The Doll's House. It tells about social oppression create by upper to dominate lower class. Upper class takes part as dominant while lower class takes part as minority in society. This research uses qualitative research. The researcher needs postcolonial theory to identify the self-positioning between upper and lower class in the short story. The analysis reveals that upper class treats lower class to be the other, subaltern and create social discrimination. The conclusion is the upper class founds powerful, otherwise the lower class is found surviving not fighting from injustice.
\end{abstract}

Keywords: Postcolonialism, Self-positioning

\section{Introduction}

The Doll's House short story by Katherine Mansfield is publish in 1922 in New Zealand which British emigrated took possession and social prejudices of native land (http://www.acschools.org). There are divides into two groups which the upper class is dominant while lower class is minority in British society. It is reflected in the short story which Burnell and Kelveys family came from different social status. Burnell takes position as superior while Kelveys takes position as inferior in the short story. The different position of dominant and minority creates the gap between the two. Social class is appearing in social interaction when the upper class tends to treat the lower class which is different with them in negative ways. It caused the social class appears in society and create discrimination is interesting to analyze further.

Dominant and minority take part in colonialism. The upper class is dominant group which dominate another in society. It caused the social domination create by upper class, especially among the lower class of landlords, peasant and servant which include in subaltern group. To analyze the problem, the researcher will do with postcolonial theory by Guha's statement in Spivak. He writes that.

Taken as a whole and in the abstract this...category...was heterogeneous in its composition and thanks to the uneven character of regional economic and social developments, different from area to area. The same class or element which was dominant in one area...could be among the dominated 
in another. This could and did create many ambiguities and contradictions in attitudes and alliances, especially among the lowest strata of the rural gentry, impoverished landlords, rich peasants and upper middle class peasants all of whom belonged, ideallys peaking, to the category of people or subaltern classes. (Guha 1982:8)

It means that upper class is dominant which dominated another in society. The domination group is like landlords, peasant and servant who include in subaltern group. The social class, social domination and subaltern are reflected in the short story which applied the postcolonial theory.

The postcolonial theory has relation with dominant group which has power and authority dominate another. The domination by dominant creates risk of colonialism. It is supported by Aschroft's statement. He also explains that.

The term 'post-colonial' to refer to any kind of marginality at all runs the risk of denying its basis in the historical process of colonialism

(Aschroft et al., 2003: 2)

It means that postcolonial is the effect or risk of colonization which have relation with superior or dominant and inferior or minority in colonialism. The colonization's effect creates by dominant to minority like domination, oppression, otherness, subaltern and discrimination. The researcher applied postcolonial theory which analyzes the social domination, otherness, subaltern and discrimination phenomena of the short story.

\section{Method}

The researcher uses qualitative method because has a relation in human life. Qualitative method also used to analyze the data taken from social context and activities of human being or human environment. The researcher gets the data of the primary data and secondary data to begin the study in qualitative research. Concerning on The Doll's House short story and resources such as journals, webs, books, articles related postcolonial theory. This research takes documentation as data collection methods because this research is qualitative research. The researcher collects the data include historical analysis, document and textual analysis investigating the text from the articles, books, journals, webs about postcolonial theory. This study uses a content analysis because the data from of text (Berg, 2001: 240).

\section{Result}

Superior has authority while inferior is powerless in colonialism. The inferior level of minority makes them get unfair treatment by dominant which minority cannot show their desire in society. Dominant and minority groups among them appear the social class in society. Dominant has authority, honor and upper social class which superior in society while minority is in 
inferior position which has lower social class, alienated and insulted by everybody. It is reflected in the short story between Burnell and Kelveys come from different level and take part in social classes which tie Kelveys down in society. Burnell is superior has authority and power while Kelveys cannot reject the Burnell's power and also cannot show their feeling because theyas inferior in society.

Inherent with assumption of colonialism, western is more dominant than orient. It builds strong belief of society. Strong belief of society is that western is as superior or dominant than the others. It is related to Said statement in Poscolonial theory by Gandi. According to Said (1979: 3) Western style for dominating, restructuring, and having authority over the Orient. It means that western is superior which has power to create social oppression in colonialism. Superior has power, strength, and authority to hold the rule of colonialism to dominate inferior in colonialism. Superior does not only dominate but also has authority to create the rule over the orient. Superior gives domination in varied ways to alienates inferior in colonialism. Superior creates social domination because of superior wants to attend their existence as the dominant group in colonialism. In other side, Inferior survives their existence by follow and obey superior rule of colonialism. Inferior cannot reject superior power and strength which has lower position in society. Inferior also cannot deliver their aspiration and desire in society. Inferior is applied the superior considerations which most dominate them because superior has power to dominates inferior in colonialism.

\section{Discussion}

The discussion will start analyzing social class take part in self-positioning. Upper and lower class are take part in colonialism. It is support by Gandi's statement. Postcolonial text shows that colonial experienced by complex cultural interaction between colonizer and colonized (Gandi, 1998: 11).Upper class settles their self to be colonizer, subject and imperialist who has power and high position in colonialism. While lower class is colonized, outsider, minority and object by superior which has lower position in colonialism. Upper class takes themselves in upper position while lower class take themselves in lower position in society called Selfpositioning. Self-positioning phenomena is reflected in the short story. Burnell takes upper position which has power and authority to treat Kelveys in society while Kelveys attends their existence which gets unfair treatment by their environment. The act is like mocking, insulting and under estimate. 
Upper class or dominant settles their self to be colonizer treat minority to be the other, subaltern and create discrimination in colonialism. Dominant treats lower class to be the other because dominant assumed that minority is different in society. The other phenomena is reflect in Staszak's statement. The otherness of western peoples has notably been based on their supposed spatial marginality (Staszak, 2008: 1). In Stazak's explanation, western and orient have spatial relationship. It is caused of western's assumptions which western more dominant than orient. It means that otherness is creation of the other by western (dominant) which assume the orient (minority) have something different in society. The other phenomena also reflected in Kelveys' life in the short story which alienates in their environment. Kelveys is different with other which never speaks and socializes in society. Kelveys is object of colonialism by Burnell and their environment which supposed to be the other by their environment because they come from poor family. The differences of them are unlike the common people who socialize with other in society, Kelveys chooses to not socialize in their environment. Kelveys and her family are being ordered because they have inferior side and different from the common society. The uncommon things make people in their environment build othering to them. People who are dominant group apply Kelveys to be the other because they have something different with other in society. In other side, Kelveys which are in minority group try to survive by living far away from society.

Dominant not only treats minority to be the other but also to be subaltern group. Subaltern is people who as subject in inferior group which oppress in society. Subaltern the oppressed subject is generally in inferior group (Gandi, 1998: 1). It means that subaltern does not have any access to elite group and cannot show up their desire because their lower position in society. Subaltern is inferior group which they are weak in economic side. It is supported by Spivak's statement.

contradictions in attitudes and alliances, especially among the lowest strata of the rural gentry, impoverished landlords, rich peasants and upper middle class peasants all of whom belonged, ideally speaking, to the category of people or subaltern classes (Spivak, 2003: 26)

It means that peasants, labor and landlords as subject of elite group in colonialism. The labor or servant oppresses and alienates in society because their position is in lower level. The minimum salary and welfare are discrimination felt by them in society. In The Doll's House, Kelveys life which has lower economic side in poorness condition. The inferior position makes them get unfair treatment by their environment. Kelveys' 
mother is servant who gets the minimum salary include subaltern people. Kelveys' parent profession and social status make them as derision of their environment.

Dominant has power and authority which create social discrimination of colonialism. Social discrimination can be domination, oppression and alienation which create by dominant to minority. It is supported by Rukundwa and Aarde. They said that.

Postcolonial theory provides a means of defiance by which any exploitative and discriminative practices, regardless of time and space, can be challenged. (Rukundwa and Aarde, 2007: 1).

It means colonizer is dominated and exploited inferior in colonialism. Discrimination can be actions, subtle or overt that served to limit the social, political or economic. Discrimination is complex system which commits in subtle or overt actions. Particular groups (dominant) discriminate the inferior in social and economic side.

In relation with postcolonial study, according to Bhaba (in Hook, 2005:11) the relationship between colonizer and colonized are complex and nuanced because the circulation of contradictory patterns of psychic affect in colonial relations it can be desire for, as well as fear of the other. The relation of colonizer (dominant) and colonized (minority) is complex because contention manner of effect physical in situation. The disagreement manners of inferior which do not have powers by superior (dominant) create discrimination among them. Inferior called the other which does not have courage to show up their desire and fear condition to superior. It is discrimination evidence of inferior in colonial. Discrimination is created by different level of dominant and minority. Dominant has an authority and power to alienate inferior. Minority is lower strata which does not have courage and desire in society. Therefore distance between upper and lower position make the discrimination among them. In The Doll's House short story discrimination create by Burnell to Kelveys can be mock, insult and bad treatment in society. Burnell has wealth and power which alienates Kelveys because Kelveys has different social status with another. The lower class make Kelveys discriminated by their environment.

Postcolonialsm consists of colonizer and colonized which takes part in colonialism. Colonizer has power and authority to hold the rule of colonialism while colonized does not any bravery to show up their desire. Colonizer has upper position which chooses equal level with them to build interaction. The lower levels which do not have any similarities with them are called inferior. The different level among 
superior and inferior creates social classes in society.

Different social class appears the gap between the two which do not built association each other in society. Upper class has power to dominate the lower class which gives unfair treatment in social, economic and culture. Upper class has power and strength to dominate inferior as related to Sarup's statement. According to Sarup (1996: 154) western is believed that they have an obligation to arrange inferior people and inferior people should be subjugated. Superior claims themselves is dominant than the other. It is reflected in Sarup's statement that superior has obligation to authorize inferior in colonialism. Superior has strength and authority to subjugate inferior and gives unfair treatment to achieve their desire. The unfair treatment felt by inferior build social discrimination because inferior has lower level in society. Social discrimination can be oppression and alienation by superior which apply in colonialism. It caused superior survives their existence as control in colonialism. Superior as subject of colonialism creates the rule of colonialism which the minority group must follow and obey it because of superior wants to attend their existence as the dominant group in colonialism.

Inferior is minority group gets social oppression by superior in colonialism. Social oppression is caused the lowest class position of inferior in society. Subaltern and the other are including minority group which gets oppression by superior. The colonized group which has something different with other is powerless to rejects superior oppression. The social oppression can be unfair treatment, insulting and mocking felt by inferior. Inferior also gets social oppression by superior which powerless to reject superior authority is reflected in Said's statement of Orientalism book. Orientalism as a western style for dominating, restructuring and having authority to over the orient (Said, 1979: 11).It means that western or superior has authority and power to dominate inferior in colonialism. In orientalism by Said, the orient or inferior is oppressed people which superior has authority of themselves. It means that inferior is oppress group which do not any bravery to reject superior authorization. Inferior do not have freedom to shows up their desire because they have lower position in society. Inferior is victim of colonialism survive their existence by follow and obey the rule of colonialism creates by superior. It is caused inferior want to survive their existence as the lowest social class and minority group in society which they is submissive people of superior authority.

Inferior do not have access with superior which inferior come from lowest social status. The lowest social status and 
poorness built unfair treatment felt by inferior which is created by superior in economic, social and culture. It is reflected in Kelveys life of the short story which gets unfair treatment by Burnell and their environment. Kelveys insult and mock in words, action and bad behavior are social oppression by Burnell and their environment.

\section{Conclusion}

The Doll's House discusses about Kelveys life which get social domination by Burnell and their environment. The researcher analyzes the self-positioning and social class phenomenon of the short story as problem one suggested. The Burnells takes themselves as dominant group while Kelveys takes themselves as minority. The different position of dominant and minority creates the gap between the two. Social class is appearing in social interaction when the upper class tends to treat lower class which is different with them in negative ways. The act is like saying rude, under estimate, and forbidden habit.

Upper class has power to hold the rule of colonialism. Upper class creates social oppression to dominate lower class which is attend upper class' authorize in colonialism. Meanwhile, minority survives their existence by following and obeying the rules of colonialism hold by dominant. Minority is submissive group which attends their existence of dominant authority. The dominant is found powerful, otherwise the minority is found surviving not fighting from injustice.

\section{Acknowledgment}

The researcher would like to gratitude to the Ngadimun gangster: Quria, Pera, Rani, Linda and Rossy who give support and motivation during the process.

\section{References}

Ashcroft, B., Griffiths, G., \& Tiffin, H. (Eds.). (2003). The Post-Colonial Studies Reader. London: Routledge.

Berg, L., B. (2001). Qualitative Research Methods for the Social Sciences (fourth ed.). Boston: Allyn and Bacon.

Bobo, L., D \& Fox, C. (2003). Race, Racism, and Discrimination: Bridging Problems, Methods, and Theory in Social Psychological Research. Social Psychology Quarterly. Vol. 66, No. 4, pp. 319-332.

Das, A., C. \& Singh, S. (2013). Discrimination and Difference, racial and Colonial: An Overview of M.G Vassanji's The Gunny Sack and No New Land. The Creation: An International Journal in English. Vol. 4, Issue 5.

Feenstra, H. (2009-2010). Circling the Self: the short story innovations of Katherine Mansfield and Virginia Woolf. INNERVATE Learning Undergraduate Work in English Studies, Vol. 2, pp 63-79.

Gandhi, L. (1998). Postcolonial Theory A critical introduction. Australia: Edinburgh University Press 
Hook, D. (2005). Paradoxes of the Other: (Post) Colonial Racism, Racial Difference, Stereotype-As-Fetish. Psychology in society. Vol. 31, pp 930.

Mannerhovi, E. (2008). The Garden as Feminine Space in Katherine Mansfield's Short Story. University of Tampere School of Modern Languages and Translation, Studies English Philology.

Rukundwa, L., S. \& Aarde, A. (2007).The Formation of Postcolonial Theory. HTS Theological Studies. Vol. 63, No. 3.

Said, E. (1979). Orientalism. New York: Vintage Books.

Sarup, M. (1996).Identity, Culture and the Postmodern World. London: Edinburgh Universit y Press

Spivak, G. C. (2003). Can the Subaltern Speak?. London: Routledge.

Stazak, F. J. (2008) Other/otherness. International Encyclopedia of human Geography. Elsevier.

Stoica, D. (2013). Reading Gayatri Chakravorty Spivak in Rural Québec, or Saving "Exotic Women from "Exotic Men": The Construction of the Religious Subaltern in Light of the 2007 Hérouxville Incident. Journal for Cultural and Religious Theory. Vol. 12, No. 3, pp 140-148. (http://www.writework.com/essay/d oll-s-house-katherine-mansfieldsummary). Accessed March 5, 2015.

Mansfield, K. (1922). What makes someone popular?.The Doll's House. (http://www.americanliterature.com/ author/katherine-mansfield/short- story/the-dolls-house). Accessed March 19, 2015.

Boddy, G. (1996). Story: Mansfield, Katherine. Dictionary of New Zealand Biography. (http://www.teara.govt.nz/en/biogra phies/3m42/mansfield-katherine). Accessed March 20, 2015. 